\title{
GAMBARAN KEPUASAN TERAPI \\ PASIEN DIABETES MELITUS TIPE 2 DI PUSKESMAS DAERAH ISTIMEWA YOGYAKARTA
}

\author{
Nur Rasdianah$^{1}$, Suwaldi Martodihardjo ${ }^{2}$, Tri Murti Andayani ${ }^{3}$, Lukman Hakim ${ }^{4}$ \\ 1) Mahasiswa Pascasarjana Ilmu Farmasi, Fakultas Farmasi Universitas Gadjah Mada dan Prodi \\ Farmasi Universitas Negeri Gorontalo, Gorontalo, Indonesia \\ 2,3,4) Pascasarjana Fakultas Farmasi, Universitas Gadjah Mada, Yogyakarta, Indonesia
}

\begin{abstract}
Success in diabetes melitus treatment not only in the efficacy and safe using of the medicine but also for the medication satisfaction. Medication satisfaction has an importan role in diabetes management. Routine rating the medicatin satisfaction for diabetes melitus patients will be useful for professional health office to identify potential problem with the patients during the therapy session. This research is the observational research with the sample taking method using accidental sampling. 123 outpatients of diabetes melitus type 2 were observed from Puskesmas in Yogyakarta during August September 2015. Research instrument using data and questioner from Diabetes Medication Satisfaction Tool (DMSAT). The Data analyzed using Chi-Square. Result of the research indicated that satisfaction level in therapy for diabetes melitus type 2 patients in quite satisfied level 49 subjects (39,4\%), and satisfied level 74 subjects $(60,16)$. Correlation for therapy satisfaction and gender $(p=0,458)$, age $(p=0,139)$, education level $(p=0,241)$, duration of the desease $(p=0,901)$, total komorbid $(p=0,130)$, history of diabetes $(0,906)$ not significant $(p>0,05)$ except ADO $(p=0,040<0,05)$. Therapy satisfaction level must be raised in order to maximize the treatment for the patient.
\end{abstract}

Keywords : Diabetes melitus, medication satisfaction, Yogyakarta

\begin{abstract}
Abstrak
Keberhasilan pengobatan diabetes melitus tidak hanya pada efikasi dan keamanan obat tetapi juga pada kepuasan terapi. Kepuasan terapi memiliki peran penting dalam pengelolaan diabetes. Penilaian kepuasan terapi secara rutin pada pasien diabetes melitus berguna bagi profesional kesehatan untuk mengidentifikasi masalah potensial yang dialami oleh pasien selama menjalani pengobatan. Penelitian ini merupakan penelitian observasional dengan metode pengambilan sampel menggunakan teknik accidental sampling. Sebanyak 123 pasien diabetes melitus tipe 2 rawat jalan direkrut dari puskesmas daerah Yogyakarta pada bulan Agustus-September tahun 2015. Instrumen penelitian berupa lembar pengambilan data dan kuesioner Diabetes Medication Satisfaction Tool (DMSAT). Data dianalisis menggunakan Chi-Square. Hasil penelitian menunjukkan bahwa tingkat kepuasan terapi pasien diabetes melitus tipe 2 berada pada kategori cukup puas sebanyak 49 subjek $(39,84 \%)$, dan kategori puas sebanyak 74 subjek $(60,16 \%)$. Hubungan antara kepuasan terapi dan jenis kelamin $(\mathrm{p}=0,458)$, usia $(\mathrm{p}=0,139)$, tingkat pendidikan $(\mathrm{p}=0,241)$, durasi penyakit $(\mathrm{p}=0,901)$, jumlah komorbid $(\mathrm{p}=0,130)$, dan riwayat diabetes $(0,906)$ tidak signifikan $(\mathrm{p}>0,05)$ kecuali ADO $(\mathrm{p}=0,040<0,05)$. Kepuasan terapi harus lebih ditingkatkan lagi untuk memaksimalkan pengobatan pasien
\end{abstract}

Kata kunci: Diabetes melitus tipe 2, karakteristik pasien, kepuasan terapi, Yogyakarta 


\section{Jurnal Delima Harapan 2019}

\section{PENDAHULUAN}

Diabetes melitus (DM) adalah gangguan metabolisme yang ditandai dengan tingginya kadar gula darah melebihi batas normal yang disebabkan oleh abnormalisme metabolisme karbohidrat, lemak, dan protein yang disebabkan oleh penurunan sekresi insulin atau penurunan sensitivitas insulin, atau keduanya dan menyebabkan suatu komplikasi kronis mikrovaskular, makrovaskular, dan neuropati (Chalik, 2012; Nugraheni dan Sari, 2015). Diabetes memerlukan manajemen pengelolaan penyakit untuk mencegah komplikasi akut dan untuk mengurangi risiko komplikasi jangka panjang. Badan kesehatan dunia (WHO) memprediksi kenaikan jumlah penderita diabetes melitus di Indonesia dari 8,4 juta pada tahun 2000 menjadi sekitar 21,3 juta pada tahun 2030. Riset kesehatan yang dilakukan pada tahun 2013 untuk diabetes melitus berdasarkan wawancara terjadi peningkatan dari $1,1 \%$ (2007) menjadi 2,4\% (2013). Prevalensi diabetes yang terdiagnosis dokter tertinggi terdapat di Daerah Istimewa Yogyakarta $(2,6 \%)$ (Litbangkes, 2013).

Kepuasan terapi adalah salah satu outcome humanis, yang dinilai dari laporan pasien diabetes (Lohr dan Zebrack, 2009). Hasil kepuasan terapi yang dilaporkan pasien telah didefinisikan sebagai laporan yang datang dari pasien tentang kondisi kesehatan dan perawatannya (Alaqeel dkk., 2012). Pengukuran kepuasan pengobatan adalah penting, karena kepuasan yang lebih besar telah ditemukan dikaitkan dengan tingkat kepatuhan yang lebih tinggi dan kepatuhan terhadap rejimen pengobatan (Atkinson dkk., 2005; Dias-Barbosa dkk., 2012). Pada pasien diabetes peningkatan kepuasan pengobatan dikaitkan dengan kontrol glikemik yang lebih baik (Brod dkk., 2010; Nicolucci dkk., 2009)

Kepuasan pasien terhadap pengobatan memiliki peranan penting dalam pengelolaan diabetes untuk mempertahankan kadar glukosa darah agar terkendali. Kepuasan dengan pengobatan tidak dapat dipisahkan sepenuhnya dari kepuasan terapi secera keseluruhan. Penilaian kepuasan terapi pada pasien diabetes melitus memiliki arti penting bagi tenaga kesehatan yang bertujuan untuk mengidentifikasi masalah potensial yang dialami oleh pasien dalam penggunaan obat, dan sebagai dasar pengambilan keputusan yang berkaitan dengan masalah kesehatan (Chalik, 2012). Penelitian ini bertujuan untuk mengetahui gambaran kepuasan terapi pasien diabetes melitus tipe 2. Penelitian ini merupakan salah satu bagian dari penelitian sebelumnya dalam rangka peyusunan pelayanan kefarmasian bagi pasien diabetes melitus tipe 2 .

\section{Metode}

Metode yang digunakan dalam penelitian ini adalah metode penelitian observasional dengan rancangan potong lintang. Penelitian dilakukan di Puskemas di Daerah Istimewa Yogyakarta pada bulan Agustus hingga Oktober 2015. Subjek penelitian ini adalah pasien diabetes melitus tipe 2 sebanyak 123 pasien yang memenuhi syarat inklusi (laki-laki dan perempuan yang berusia $\geq 18$ tahun; terdiagnosis oleh dokter menderita diabetes melitus tipe 2; mendapat terapi obat hipoglikemik oral tunggal/kombinasi dan/ atau insulin; mampu berbahasa Indonesia; bersedia mengikuti penelitian) dan esklusi (pikun, mengalami gangguan pendengaran, dan tidak mampu diajak berkomunikasi). Pengambilan data dilakukan setelah mendapatkan persetujuan pasien (Ethical Clearance Ref: KE/FK/900/EC/2015).

Pengumpulan data secara retrospektif (data umum) dan pengisian kuesioner (concurrent). Kuesioner yang digunakan untuk mengukur kepuasan terapi adalah DiabetesMedication Satisfaction Tool (DMSAT) yang terdiri dari 16 pernyataan (Anderson dkk., 2009). Hasil uji validitas dan realibilitas 


\section{Jurnal Delima Harapan 2019}

instrumen penelitian DMSAT diperoleh rhitung > 0,300 dan 0,361 dan cronbach alpha $=(0,967$ dan 0,905) $>$ rtabel (Chalik, 2012; Nugraheni dan Sari, 2015). Hasil dari pengukuran kepatuhan dikategorikan menjadi lima tingkatan yaitu sangat tidak puas bila skor 0 , tidak puas bila skor $1,2,3$, cukup puas bila skor 4,5,6, puas bila skor 7,8,9, sangat puas bila skor 10. Hasil pengukuran dalam bentuk persentase dan disajikan dalam bentuk tabel. Data dianalisis dengan Chi Square.

\section{Hasil}

\section{Karakteristik Sosiodemografi Pasien}

Berdasarkan hasil penilaian karakteristik sosiodemografi subjek penelitian, terdapat sebanyak 123 subjek yang memenuhi kriteria inklusi dan ekslusi dari tujuh puskemas di Daerah Istimewa Yogyakarta. Karakteristik pasien disajikan dalam Tabel 1.

Tabel 1. Karakteristik pasien diabetes melitus tipe 2 di puskesmas. kurang dari 60 tahun sebanyak 74 orang $(62,4 \%)$ dan $\geq 60$ tahun sebanyak 49 orang (39,8\%). Tingkat pendidikan rendah sebanyak 61 orang $(49,6 \%)$ dan pendidikan menengah sebanyak 60 orang $(48,8 \%)$. Berdasarkan faktor karakteristik penyakit dan pengobatan, pasien dengan durasi penyakit kurang dari 5 tahun sebanyak 89 orang $(72,4 \%)$, pasien yang menderita komorbid sebanyak 66 orang $(46,4 \%)$, Subjek yang mendapat pengobatan antidiabetik oral kombinasi sebanyak 69 orang $(56,1 \%)$ dan pasien yang memiliki riwayat keluarga menderita diabetes sebanyak 72 orang $(58,54 \%)$. Berdasarkan pengaturan gaya hidup, subjek yang tidak memiliki pengaturan pola makan khusus sebanyak 96 orang $(78,05 \%)$. Subjek yang tidak melakukan olah raga sebanyak 74 orang $(60,2 \%)$. Subjek yang tidak merokok sebanyak 118 orang $(95,93 \%)$.

\section{Kepuasan terapi}

Berdasarkan hasil skor kuesioner DMSAT dari 123 partisipan, diketahui sebanyak 49 orang memiliki tingkat kepuasan terapi pada kategori cukup puas dan sebanyak 74 orang pada kategori puas. Tidak ada subjek yang mempunyai tingkat kepuasan terapi pada kategori sangat puas.

\begin{tabular}{|c|c|c|c|c|c|c|c|c|}
\hline Variabel & kategori & $\mathrm{n}(123)$ & \multirow{2}{*}{ 25,2 kepuasan terapi pada kategori cukup } & \multirow{2}{*}{\multicolumn{5}{|c|}{$\begin{array}{l}\text { sebanyak } 49 \text { orang memilik1 tingkat } \\
\text { kepuasan terapi pada kategori cukup }\end{array}$}} \\
\hline \multirow[t]{2}{*}{ Jenis kelamin } & Laki-laki & 31 & & & & & & \\
\hline & Perempuan & 92 & \multirow{2}{*}{\multicolumn{6}{|c|}{$\begin{array}{l}14,8 \text { kategori puas. Tidak ada subjek yang } \\
60,2 \text { mempunyai tingkat kepuasan terapi pada }\end{array}$}} \\
\hline \multirow[t]{2}{*}{ Usia } & $<60$ tahun & 74 & & & & & & \\
\hline & $\geq 60$ tahun & 49 & \multicolumn{6}{|c|}{39,8 mempunyai tingkat kepuasan terapi pada } \\
\hline \multirow[t]{3}{*}{ Tingkat pendidikan } & Rendah & 61 & \multicolumn{6}{|l|}{49,6} \\
\hline & Menengah & 60 & \multicolumn{6}{|c|}{48,8} \\
\hline & Tinggi & 2 & \multicolumn{6}{|c|}{1,6} \\
\hline \multirow[t]{2}{*}{ Durasi penyakit } & $<5$ tahun & 89 & \multicolumn{6}{|l|}{72,4} \\
\hline & $\geq 5$ tahun & 34 & \multirow{3}{*}{\multicolumn{2}{|c|}{$\begin{array}{l}\frac{27,6}{46,4} \\
53,6\end{array}$}} & \multirow[t]{3}{*}{ Kategori } & \multicolumn{2}{|c|}{ Tingkat kepuasan } & Total \\
\hline \multirow[t]{2}{*}{ Komorbid } & Tanpa komorbid & 57 & & & & \multirow{2}{*}{\multicolumn{2}{|c|}{ Cukup puas }} & \\
\hline & Dengan Komorbid & 66 & & & & & & \\
\hline \multirow[t]{2}{*}{$\mathrm{ADO}$} & Tunggal & 54 & 43,9 & $\begin{array}{l}\text { Jenis } \\
\text { kelamin }\end{array}$ & $\begin{array}{l}\text { Laki-laki } \\
\text { Peremnuna }\end{array}$ & $\begin{array}{l}17(34,69) \\
32(65,31)\end{array}$ & $17(22,97)$ & $\begin{array}{l}34 \\
89\end{array}$ \\
\hline & Kombinasi & 69 & $56,1^{-1}$ & Usia & $<60$ tahun & $31(63,27)$ & $56(75,68)$ & 87 \\
\hline \multirow[t]{2}{*}{ Riwayat Keluarga } & Ya & 72 & \multirow{2}{*}{58,5} & & $\geq 60$ tahun & $18(36,73)$ & $18(24,32)$ & 36 \\
\hline & Tidak & 51 & & \multirow[t]{2}{*}{ Tingkat } & Rendah & $28(67,14)$ & $33(44,60)$ & 61 \\
\hline \multirow[t]{2}{*}{ Pola makan } & Ya & 27 & \multirow{2}{*}{$\begin{array}{l}21,9 \\
78,1\end{array}$} & & Tinggi & 0 & $2(2,70)$ & 2 \\
\hline & Tidak & 96 & & Durasi & $<5$ tahun & $31(63,27)$ & $46(62,16)$ & 77 \\
\hline \multirow[t]{2}{*}{ Olah raga } & Ya & 49 & \multirow{3}{*}{$\begin{array}{l}39,8 \\
60,2\end{array}$} & \multirow{3}{*}{ Komorbid } & $\geq 5$ tahun & $18(36,73)$ & $28(37,84)$ & 46 \\
\hline & Tidak & 74 & & & \multirow{2}{*}{$\begin{array}{l}\text { Tanpa } \\
\text { komorbid } \\
\text { Dengan } \\
\text { komorbid }\end{array}$} & $30(61,22)$ & $35(47,30)$ & \multirow[t]{2}{*}{$\begin{array}{l}65 \\
58\end{array}$} \\
\hline \multirow{3}{*}{\multicolumn{3}{|c|}{$\begin{array}{l}\text { Berdasarkan jenis kelamin, jumlah } \\
\text { perempuan sebanyak } 92 \text { orang }(74,8 \%) \\
\text { lebih banyak dibandingkan dengan laki- }\end{array}$}} & & & & $19(38,78)$ & $39(52,70)$ & \\
\hline & & & & ADO & $\begin{array}{l}\text { Tunggal } \\
\text { Kombinasi }\end{array}$ & $\begin{array}{l}17(34,69) \\
32(65,31)\end{array}$ & $\begin{array}{l}14(18,92) \\
60(81,08)\end{array}$ & $\begin{array}{l}31 \\
92\end{array}$ \\
\hline & & & & $\begin{array}{l}\text { Riwayat } \\
\text { DM }\end{array}$ & $\begin{array}{l}\text { Ya } \\
\text { Tidak }\end{array}$ & $\begin{array}{l}29(59,18) \\
20(40,89)\end{array}$ & $\begin{array}{l}43(58,11) \\
31(41,89)\end{array}$ & $\begin{array}{l}72 \\
51\end{array}$ \\
\hline
\end{tabular}




\section{Jurnal Delima Harapan 2019}

Berdasarkan hasil penelitian pada Tabel 2, perempuan memiliki tingkat kepuasan terapi pada kategori puas sebesar 77,03\% lebih tinggi dari pada laki-laki $(22,97)$, subjek dengan usia < 60 tahun sebanyak 56 orang $(75,68 \%)$, tingkat pendidikan menengah sebanyak 39 orang $(52,70 \%)$, durasi penyakit 46 orang $(62,16 \%)$, pasien diabetes dengan komorbid sebanyak 39 orang $(52,70 \%)$, ADO kombinasi sebanyak 60 orang $(81,08)$ dan memiliki riwayat keluarga yang menderita diabetes sebanyak 43 orang $(57,11 \%)$.

Berdasarkan uji statistik menggunakan Statistical Product and Service Solution (SPPS) 16 Chi-Square, pengaruh jenis kelamin, usia, pendidikan, durasi penyakit, komorbid, dan riwayat keluarga penderita diabetes tidak menunjukkan adanya hubungan yang signifikan terhadap tingkat kepuasan terapi (nilai $\mathrm{p}>0,05$ ). Pengaruh pemakaian antidiabetes oral (ADO) tunggal dan kombinasi menunjukkan adanya hubungan yang signifikan (nilai $\mathrm{p}=0,04<0,05)$ dengan kepuasan terapi. Hasil pengujian dapat dilihat pada Tabel 3.

Tabel 3. Hasil analisis pengaruh variabel karakteristik terhadap tingkat kepuasan terapi.

\begin{tabular}{lll}
\hline \multirow{2}{*}{ Variabel } & \multicolumn{2}{c}{ Tingkat kepuasan } \\
\cline { 2 - 3 } & Nilai & Signifikansi* \\
\hline Jenis kelamin & 0,551 & 0,458 \\
\hline Usia & 2,193 & 0,139 \\
\hline $\begin{array}{l}\text { Tingkat } \\
\text { pendidikan }\end{array}$ & 2,846 & 0,241 \\
\hline Durasi penyakit & 0,015 & 0,901 \\
\hline $\begin{array}{l}\text { Jumlah } \\
\text { Komorbid }\end{array}$ & 2,295 & 0,130 \\
\hline ADO & 3,892 & 0,040 \\
\hline Riwayat DM & 0,014 & 0,906 \\
\hline *chi square & &
\end{tabular}

\section{Pembahasan}

\section{Karakteristik Partisipan}

Berdasarkan hasil penelitian pada variabel jenis kelamin, diketahui jumlah pasien diebetes dengan jenis kelamin perempuan sebanyak 92 orang $(74,8 \%)$ lebih banyak dibandingkan dengan lakilaki. Hal ini disebabkan karena jumlah perempuan yang berkunjung ke puskesmas lebih banyak dari laki-laki. Penelitian lain menunjukkan bahwa perempuan lebih sensitif terhadap penyakit, lebih mampu dan cenderung beristirahat bila menderita suatu penyakit, dan lebih bersedia untuk mencari nasihat medis. Wanita cenderung terbuka untuk mengungkapkan status penyakit dirasakan dan lebih mudah mengintegrasikan manajemen dalam kehidupan sehari-hari, sedangkan pria lebih tertutup atau enggan membicarakan penyakitnya dan kurang jeli menerapkan praktik manajemen diri (Carretero dkk., 2014; Mathew dkk., 2012). Berdasarkan usia partisipan, kelompok usia yang menderita diabetes melitus dibawah 60 tahun sebanyak 74 orang $(62,4 \%)$ dan kelompok umur diatas 60 tahun sebanyak 49 orang (39,8\%). Menurut hasil riset (2013) prevalensi diabetes melitus berdasarkan diagnosis dokter dan gejala meningkat sesuai dengan bertambahnya umur, namun mulai umur $\geq 65$ tahun cenderung menurun (Litbangkes, 2013). Guariguata dkk., (2014) melaporkan prevalensi diabetes meningkat dengan bertambahnya usia di semua wilayah dan kelompok pendapatan. Prevalensi spesifik usia tertinggi adalah pada orang yang berusia 60-79 tahun, meskipun jumlah terbesar penderita diabetes adalah pada kelompok usia 40-59 tahun. Pola-pola ini diperkirakan akan bertahan selama 20 tahun ke depan. Studi lain menunjukkan bahwa pasien dalam kelompok usia menengah 36-50 tahun memiliki kepatuhan yang rendah sehingga kadar gula darah tidak terkendali (Kalyango dkk., 2008; Rwegerera, 2014). Pasien lansia penderita diabetes melitus yang usianya semakin menua, biasanya akan mengalami sindrom geriatri dan kejadian hipoglikemia, yang akan mempengaruhi tingkat komplikasi diabetes, sehingga pencegahan komplikasi pada pasien usia 


\section{Jurnal Delima Harapan 2019}

lanjut harus diatasi dengan mencegah hipoglikemia yang dapat memperparah penyakit.

Sebanyak 58,5\% partisipan memiliki riwayat keluarga yang menderita diabetes. Distribusi durasi penyakit kurang dari 5 tahun sebanyak 89 orang $(72,4 \%)$, dan didominasi kelompok diabetes melitus dengan komorbid sebanyak 53,6\%. hasil penelitian ini berbeda dengan hasil penelitian lain (Nugraheni dan Sari, 2015). Berdasarkan pengaturan gaya hidup, partisipan yang tidak memiliki pengaturan pola makan khusus sebanyak 96 orang $(78,05 \%)$. Partisipan yang tidak melakukan olah raga sebanyak 74 orang $(60,2 \%)$. partisipan yang tidak merokok sebanyak 118 orang $(95,93 \%)$. Faktor yang berhubungan dengan gaya hidup dianggap sebagai komponen penting untuk mengelola diabetes. Partisipan yang menyadari pentingnya pengaturan gaya hidup merasakan perlu untuk menyesuaikan pola makan, melakukan aktivitas fisik dan berupaya untuk menerima keadaan dengan mengatur suasana hati. Partisipan yang tidak mampu mengelola pola makan memiliki alasan seperti mengalami kendala sehubungan dengan diet, mengalami kesulitan mengelola pola makan yang benar, pasien tidak mengerti konsep diet sehat, pasien menganggap bahwa diet mengurangi kesenangan atau hobbi makan makanan yang mereka sukai. Alasan lain pasien beranggapan bila diet sudah dilakukan maka obat tidak perlu lagi diminum. Selain itu ada pasien yang beranggapan bahwa mengurangi frekuensi makan dari tiga kali sehari menjadi sekali sehari akan memperbaiki kadar gula darah. Faktor-faktor tersebut yang menjadi alasan partisipan tidak merasa perlu mengatur pola makan

\section{Kepuasan Terapi}

Sebanyak $49 \quad(39,8 \%)$ orang memiliki tingkat kepuasan terapi pada kategori cukup puas dan sebanyak 74 $(60,2 \%)$ orang pada kategori puas. Secara keseluruhan tingkat kepuasan terapi pada pasien diabetes melitus tipe 2 yang menjalani pengobatan merasa puas dengan terapi yang dijalani. Kepuasan terapi yang dirasakan pasien dapat disebabkan karena pasien menganggap terapi diabetes merupakan suatu kebutuhan sehingga mereka rutin kontrol kesehatan ke dokter setiap bulannya. Penelitian lain yang mengukur faktorfaktor yang mempengaruhi kepuasan pengobatan diabetes. Brod dkk menemukan bahwa tingkat kepuasan terapi pasien lebih rendah apabila dikaitkan dengan komorbiditas, hipoglikemia, dan kenaikan berat badan (Brod dkk., 2010). Nicolucci dkk menemukan bahwa kepuasan pengobatan yang lebih rendah dikaitkan terjadi pada pasien perempuan, menggunakan insulin, dan memiliki komplikasi diabetes. Peneliti lain mencatat bahwa pasien dengan hipoglikemia melaporkan penurunan yang signifikan dalam kepuasan pengobatan dan kualitas hidup yang lebih rendah, dan tingkat pemanfaatan sumber daya layanan kesehatan yang lebih tinggi (Pollack dkk., 2009; Williams dkk., 2011). Biderman dkk menemukan bahwa kepuasan pengobatan secara signifikan berbeda antara pilihan pengobatan dimana tingkat kepuasan lebih rendah pada pasien yang menggunakan insulin dibanding dengan penggunaan obat diabetes oral (Biderman dkk., 2009).

\section{Hubungan antara kepuasan terapi dan karakteristik partisipan}

Hubungan antara skor kepuasan terapi dan jenis kelamin $(\mathrm{p}=0,458)$, usia $(\mathrm{p}=0,139)$, tingkat pendidikan $(\mathrm{p}=0,241)$, durasi penyakit $(\mathrm{p}=0,901)$, jumlah komorbid $(\mathrm{p}=0,130)$, dan riwayat diabetes $(0,906)$ tidak signifikan $(\mathrm{p}>0,05)$. Sedangkan variabel penggunaan ADO menunjukkan terdapat hubungan yang signifikan secara statistik antara skor kepuasan terapi dan penggunaan antidiabetes oral ADO $(\mathrm{p}=0,040<0,05)$. Pasien yang puas lebih patuh dalam minum obat mereka, mengubah kebiasaan diet, melakukan 
aktivitas fisik, dan melakukan kontrol secara rutin.

\section{Kesimpulan}

Kepuasan terapi masih pada kategori cukup puas dan puas. Belum mencapai tahap sangat puas, sehingga diperlukan upaya yang berkelanjutan untuk memaksimalkan pengobatan pasien diabetes melitus.

\section{Ucapan Terima Kasih}

Terima kasih kepada pihak puskesmas Daerah Istimewa Yogyakarta yang telah membantu jalannya penelitian ini.

\section{Pendanaan}

Penelitian ini tidak menggunakan dana hibah atau dana bantuan dari sumber manapun.

\section{Konflik Kepentingan}

Tidak ada konflik kepentingan dalam penelitian ini

\section{Daftar Pustaka}

Alaqeel, S.A., Aujan, S., AlHarbi, dan Al Abdulatief, 2012. Patients\&rsquo; satisfaction with diabetes medications in one hospital, Saudi Arabia. Patient Preference and Adherence, 735.

Anderson, R.T., Girman, C.J., Pawaskar, M.D., Camacho, F.T., Calles, J., Kelly, W.S., dkk., 2009. Diabetes Medication Satisfaction Tool: A focus on treatment regimens. Diabetes Care, 32: 51-53.

Atkinson, M.J., Kumar, R., Cappelleri, J.C., dan Hass, S.L., 2005. Hierarchical Construct Validity of the Treatment Satisfaction Questionnaire for Medication (TSQM Version II) among Outpatient Pharmacy Consumers. Value in Health, 8: S9-S24.

Biderman, A., Noff, E., Harris, S.B., Friedman, N., dan Levy, A., 2009. Treatment satisfaction of diabetic patients: what are the contributing factors? Family Practice, 26: 102108.
Brod, M., Valensi, P., Shaban, J.A., Bushnell, D.M., dan Christensen, T.L., 2010. Patient treatment satisfaction after switching to NovoMix ${ }^{\circledR} 30$ (BIAsp 30) in the IMPROVE ${ }^{\mathrm{TM}}$ study: an analysis of the influence of prior and current treatment factors. Quality of Life Research, 19: 1285-1293.

Carretero, M.T., Calderón-Larrañaga, A., Poblador-Plou, B., dan PradosTorres, A., 2014. Primary health care use from the perspective of gender and morbidity burden. $B M C$ Women's Health, 14: .

Chalik, R., 2012. 'Kepatuhan dan Kepuasan Terapi dengan Antidiabetik Oral pada Pasien Diabetes melitus Tipe 2 Rawat Jalan di RSUP Dr. Sardjito Yogyakarta', . Universitas Gadjah Mada, Yogayakarta.

Dias-Barbosa, C., Balp, Kulich, K., Germain, N., dan Rofail, D., 2012. A literature review to explore the link between treatment satisfaction and adherence, compliance, and persistence. Patient Preference and Adherence, 39.

Guariguata, L., Whiting, D.R., Hambleton, I., Beagley, J., Linnenkamp, U., dan Shaw, J.E., 2014. Global estimates of diabetes prevalence for 2013 and projections for 2035. Diabetes Research and Clinical Practice, 103: 137-149.

Kalyango, J.N., Owino, E., dan Nambuya, A.P., 2008. Nonadherence to diabetes treatment at Mulago Hospital in Uganda: prevalence and associated factors $\mathbf{8}$ : 7.

Litbangkes, B., 2013. Hasil Riset Kesehatan Dasar (Riskesdas) 2013.

Lohr, K. dan Zebrack, B., 2009. Using patient-reported outcomes in clinical practice: challenges and opportunities. Qual Life Res, 18: 99-107.

Mathew, R., Gucciardi, E., De Melo, M., dan Barata, P., 2012. Selfmanagement experiences among men and women with type 2 
diabetes mellitus: a qualitative analysis. BMC Family Practice, 13:

Nicolucci, A., Cucinotta, D., Squatrito, S., Lapolla, A., Musacchio, N., Leotta, S., dkk., 2009. Clinical and socio-economic correlates of quality of life and treatment satisfaction in patients with type 2 diabetes. Nutrition, Metabolism and Cardiovascular Diseases, 19: 4553.

Nugraheni, A.Y. dan Sari, I.P., 2015. Pengaruh Konseling Apoteker Dengan Alat Bantu Pada Pasien Diabetes Melitus Tipe 2 5: 8.

Pollack, M., Chastek, B., dan Williams, S., 2009. Impact of Treatment Complexity on Adherence and Glycemic Control: An Analysis of Oral Anti-Diabetic Agents. Value in Health, 12: A103.

Rwegerera, G.M., 2014. Adherence to anti-diabetic drugs among patients with Type 2 diabetes mellitus at Muhimbili National Hospital, Dar es Salaam, Tanzania- A crosssectional study. Pan African Medical Journal, 17: .

Williams, S., Pollack, M., dan DiBonaventura, M., 2011. Effects of hypoglycemia on health-related quality of life, treatment satisfaction and healthcare resource utilization in patients with type 2 diabetes mellitus. Diabetes Res Clin Pract, 91: 363-370. 